\title{
The Influence of Intellectual Capital on Knowledge Sharing: Small and Medium Enterprises' Perspective
}

\author{
Rohana Ngah ${ }^{1}$ and Abdul Razak Ibrahim ${ }^{2}$ \\ ${ }^{1}$ Malaysian Academy of Entrepreneurship, Universiti Teknologi MARA, Malaysia \\ ${ }^{2}$ Faculty of Business and Accountancy, Universiti Malaya, Kuala Lumpur, Malaysia
}

\begin{abstract}
Intellectual capital of the organization would determine the success of the organization itself if it is well capitalized. Knowledge sharing is a platform for the organization to further enhance productivity. Furthermore, knowledge sharing is always linked to small and medium enterprises (SMEs) due to their advantage of being small. Convenience sampling was used for manufacturing and services industries of SMEs. Data was tested using Structural Equation Modeling (SEM) to investigate the impact of intellectual capital on knowledge sharing. Measurement model and structural model were developed. Findings show that relational capital has a positive impact on knowledge sharing while human capital and structural capital has negative impact on knowledge sharing. All the intellectual capital dimensions contributed a significant impact on knowledge sharing. It is important for SMEs to invest and focus on knowledge sharing activity as it would create a platform for innovation, thus enhances the performance.
\end{abstract}

Keywords: Human capital, structural capital, relational capital, knowledge sharing, small and medium enterprises

\section{Introduction}

Knowledge is vital for most of the organizations nowadays, hence, organization must take a big step to change. The first step to change from a traditional company into a knowledge company is to be aware of the knowledge of the organization, known as intellectual capital (IC) (Montequin et al., 2006). Recently, the concept of intellectual capital has been identified as a key resource and driver of organizational performance and value creation (Marr et al., 2004). Organizations perform well and create value when they implement strategies that respond to market opportunities by exploiting their internal resources and capabilities (Penrose, 1959; Andrews, 1971 as cited by Marr et al., 2004).

Knowledge sharing has been highly regarded as an important process in enhancing organizational performance as emphasized by Nonaka and Takeuchi (1995) on their SECI knowledge circle. However, knowledge sharing is not easy to be implemented. Sharing knowledge requires willingness, trust, conducive and suitable environment in

Copyright (C) 2011 Rohana Ngah and Abdul Razak Ibrahim. This is an open access article distributed under the Creative Commons Attribution License unported 3.0, which permits unrestricted use, distribution, and reproduction in any medium, provided that original work is properly cited. Contact author: Rohana Ngah emaill: rohanangah@salam.uitm.edu.my 
order for the effective knowledge sharing to take place. This study is to investigate the impact of intellectual capital dimensions, namely human capital, structural capital and relational capital on knowledge sharing in the small and medium enterprises.

This paper is organized into four sections: Section 1 will discuss on intellectual capital and knowledge sharing. Section 2 will discuss the research design. Section 3 is the findings and Section 4 will conclude.

\section{Literature Review}

Intellectual capital can be located in its people, its structures and its customers (Stewart, 1997). Intellectual capital is defined as the organizational resources which comprise human capital, structural capital and relational capital (Bontis, 1998). Edvinson (1997) define intellectual capital as the possession of knowledge, applied experience, organizational technology, customer relationships and professional skills that provide Skandia with a competitive edge in the market. Roos and Roos (1997) define intellectual capital as the sum of the hidden assets of the company not fully captured on the balanced sheet and thus, it includes both what is in the heads of the organizational members and what is left in the company when they leave. Bontis (1998) define intellectual capital as the pursuit of effective use of knowledge (the finished product) as opposed to information (the raw material). Stewart (1997) explains that human capital is the accumulated capabilities of individual responsible for providing customer solutions. Structural capital refers to the capabilities of the organization to meet market requirements and relational capital refers to the extent and intensity of the organizations' relationships with customers. The three types of capital are interrelated (Johnson, 1999).

\section{Human Capital}

The employees in the organization made up the human capital of the organization (Bontis et al., 2000). Employees are the most important resources in the organization (Chen et al., 2004). Known as human capital, employees' skills, commitment, capabilities, talents and knowledge are organization's intangible assets that can be turned into its competitive advantage (Yang et al., 2007). The human capital of one organization to another organization is totally different and that makes it difficult to imitate, difficult to copy, rare and non-replaceable. Knowledge must be managed effectively in people and organizations to ensure that wealth creating capacity can be maintained (Bohn, 1994 as cited in Martinez-Torres, 2006). Human capital represents the individual tacit knowledge embedded in the mind of the employees. It can be defined as a combination of employee's competence, attitude and creativity (Jin Chen et al., 2004). According to Mayo (2001), human capital can be divided into three dimensions: capability and potential, motivation and commitment and innovation and learning.

For SMEs, the entrepreneur and the inventor are pure human capital (Hisrich et al, 2008). An SME is more than the owner itself, it is about the people who make things going and make profit for the organization. The most important in human capital is about what people can do, individually and collectively (Brennan and Connell, 2000).

\section{Structural Capital}

Intellectual capital by itself is of little value without the leveraging effect of the firm's supporting structural capital resource (Stewart, 1997). The structural capital comprises systems, structure, corporate culture, the organizational process efficiency, data bases, information and production technology (Bontis, 1998). Structural capital is the embodiment, empowerment, and supportive infrastructure of human capital. It provides the environment that encourages individuals to invest their human capital to create and leverage its knowledge (Cohen and Kaimenakis, 2007). The structural capital encompasses all forms of knowledge deposit from human capital which is not supported by employees such as organizational routines, 
strategies, process handbooks and databases and many more (Boisot, 2002; Walsh and Ungson, 1991; Pablos, 2007). It also encompasses the organizational capacity, including the physical systems used to transmit and store intellectual material (Edvinsson and Malone, 1997). This component of intellectual capital is the firm's infrastructure that develops to commercialize their intellectual capital (Edvinsson and Sullivan, 1996). Unlike human capital, structural capital can be formally captured and embedded (Tan et al., 2008). Structural capital provides a platform for people to be creative (Stewart, 2000). While firms do not own human capital (Cohen and Kaimenakis, 2007), structural capital belongs to the organization. It can be reproduced and shared. A good structural capital will provide a good environment for rapid knowledge sharing, collective knowledge growth, shortened lead times and more productive people (Stewart, 2000). In fact, Stewart (2000) also refers to structural capital as knowledge management whereby the knowledge of an organization is flowing in this capital. The system in the structural capital is the knowledge of the company which is independent of people (Brennan and Connell, 2000).

\section{Relational Capital}

Relational capital embraces all the relations the firm has established with its stakeholder groups such as customers, suppliers, community, and government (Bontis, 1998; Allee, 2000). Most of references refer to the third part of intellectual capital as customer capital as those authors are relating it to the market orientation and customer orientation. However, for the purpose of this study, relational capital will be adopted. Many nations are improving economically in today's knowledge-based economy by promoting and supporting SMEs with necessary infrastructure (Cowey, 2003 as in Wickramansinghe and Sharma, 2005). Stewart (2000) points out that the relationship with these external stakeholders is to turn it into money.
The information from the market is turned into market orientation while information of customer is referred to as customer orientation. Customer capital is closely related to market orientation (Cohen and Kaimenakis, 2007). Market orientation is a set of behaviors and processes (Kohli and Jaworski, 1990) or an aspect of culture (Narver and Slater, 1990) to create a superior customer value. Market orientation is also an implementation of marketing concept via market intelligence generation, intelligence, dissemination and responsiveness; that is implementing a marketing strategy (Kohli and Jaworski, 1990). Han et al (1998) emphasize that market orientation is to coordinate the customer's needs by obtaining and using customer's information, competitor's capabilities and provision of other significant market agents and authorities (Keskin, 2006; Deshpande and Webster, 1989). This integrated effort on the part of the employees and across departments in an organization in turn gives high or superior performance to an organization (Kohli and Jaworski, 1990). Customer orientation is defined as an integral component of a general, underlying organizational culture. Hence, attention to the information about customers' needs should be considered alongside the basic set of values and beliefs that are likely to reinforce such as customer focus and permeate the firm (Appiah-Adu and Singh, 1998). They emphasize, that in SMEs, customer orientation is vital determinant of success because of its advantages of close proximity to their customers. Deshpande and Webster (1993) found the positive relationship between customer orientation and organizational performance.

Specifically, relational capital fosters a knowledge-producing behavior - providing a source of ideas for change and improvement by market information processing and marketing strategies (Keskin, 2006). However, this knowledge has little benefit if not appreciated and implemented for firm innovation. Contemporary classical schemes have divided intellectual capital into the 
categories of external (customer-related) capital, internal (structural) capital and human capital ( Sveiby, 1997; Roos et al., 1998; Stewart, 1997; Edvinsson and Malone, 1997; Petty and Guthrie, 2000). In conclusion, it appears that most of the definitions of intellectual capital listed above include human capital, structural capital and relational capital.

The three IC components (human capital, structural capital and relational capital) are closely intertwined and interdependent (Subramaniam and Youndt, 2005; Youndt, Subramaniam and Snell, 2004). The IC must have human capital, structural capital and relational capital in order for the organization to achieve its goal. IC provides the best possible value to organizations through the combination, utilization, interaction, alignment and balancing of the three types of intellectual capital as well as managing the knowledge flow between the three components (Quink, 2008).

Tacit knowledge is a tremendous resource for all activities especially for innovation (Leonard and Sensiper, 1998). Tacit knowledge is what embedded in the mind (Choi and Lee, 2003), can be expressed through ability applications; is transferred in the form of learning by doing and learning by watching. Knowledge sharing is basically the act of making knowledge available to others within the organization (Ipe, 2003). Knowledge sharing can also be explained as a set of behaviors that involve the exchange of information or assistance to others and it is separate from information sharing (Connelly and Kelloway, 2003). Knowledge sharing enables managers to keep the individual learning flow throughout the company and integrate it for practical application.

From the perspective of the flow approach of intellectual capital, knowledge resources are flowing through its people, structure and relationship to create value. The flow process needs a mechanism to represent the basic operations of knowledge. In this study, knowledge sharing is identified as knowledge processes for intellectual capital. This relationship can be found in the inputprocess-output model by Hackerman and Moris (1978). Lee and Choi (2003) demonstrate further this model when they applied seven enablers which they called knowledge enablers to interconnect knowledge management factors. The human interaction is limited to t-shaped skills rather than the social interaction among the people.

Knowledge is important in intellectual capital that needs to produce higher-valued asset. Intellectual capital is tacit - and tacit knowledge cannot be sold no matter how much someone is willing to fork over (Stewart, 2000; pp.74). People develop and use tacit knowledge before they formalize or codify it. But Awad and Ghaziri (2004) stress that knowledge management is not intellectual capital as defined clearly by Wiig (1997):

-Intellectual capital focuses on building and governing intellectual assets from strategic and enterprise governance perspectives

- Knowledge management has tactical and operational perspectives in facilitating and managing knowledge.

Widen-Wuff and Suomi (2003) found that intellectual capital needs a process mechanism which is knowledge sharing to give an impact on business performance as in the research conducted in Finland. Organizational slack, human capital and ICT infrastructure are the base of the process which then support learning organization metaphor, intellectual capital and knowledge sharing in process which eventually lead to knowledge sharing and business success.

Ruta and Macchitella (2008) highlight that three dimensions of intellectual capital can influence the motivation of individuals to share their knowledge with other members within the organization. Koenig (1998) stresses that in order for knowledge to be circulated evenly in the organization, it must be supported by other factors such as culture, trust, knowledge behavior and human capital 
and structural capital of processes, resources, technology and metric.

\section{Research Design and Methodology}

\section{Hypothesis Development}

This paper examines the impact of intellectual capital on knowledge sharing. The intellectual capital is represented by human capital, structural capital and relational capital which would be tested against knowledge sharing.

Employees are the main element in the knowledge sharing activity. When people get together and involve in knowledge-based discussion, they would share their personal knowledge with their colleagues. The knowledge regardless of its nature, tacit, explicit, formal or informal must be circulated in order for the knowledge to be beneficial to the organization. This knowledge flow would increase the value of the existing knowledge as expanded knowledge becomes valuable and meaningful. The structural capital is not only a mechanism to take advantage of the information and knowledge, but also a mechanism to capture, store, retrieve and communicate the knowledge and information (Koenig, 1984).

The knowledge either tacit or explicit which is acquired and gathered through the interaction with customers, suppliers or any outside party would help the organization to generate, acquire and restore its knowledge asset. Tacit knowledge is the key element of knowledge sharing, and the knower must be willing to share the knowledge. Factors such as motivation of the sender and recipient (Huber, 2001), reward and benefit of sharing (Gupta and Govindarajan, 2000, Kaiser and Miles, 2001, Dyer and Nobeoka, 2000), technical ease of sharing (Decarolis and Deeds, 1999) the utilization of shared knowledge (Cohen and Levinthal, 1990) and the characteristics of the knowledge (Gupta and Govindarajan, 2000) are among others important to facilitate the movement of knowledge within and between organizations. Human capital has indirect impact on performance and has impact on performance through structural capital and relational capital (Bontis et al , 2000; Chen et al, 2004).

- H1: Higher levels of Structural Capital and Relational Capital lead to higher levels of Knowledge Sharing.

- H2: Human Capital has positive impact on Relational Capital.

- H3: Human Capital has positive impact on Structural Capital.

- H4: Relational capital has a positive impact on Knowledge Sharing.

Based on the literature review and hypotheses developed, a framework that guides the study has been developed as in Figure 1.2.

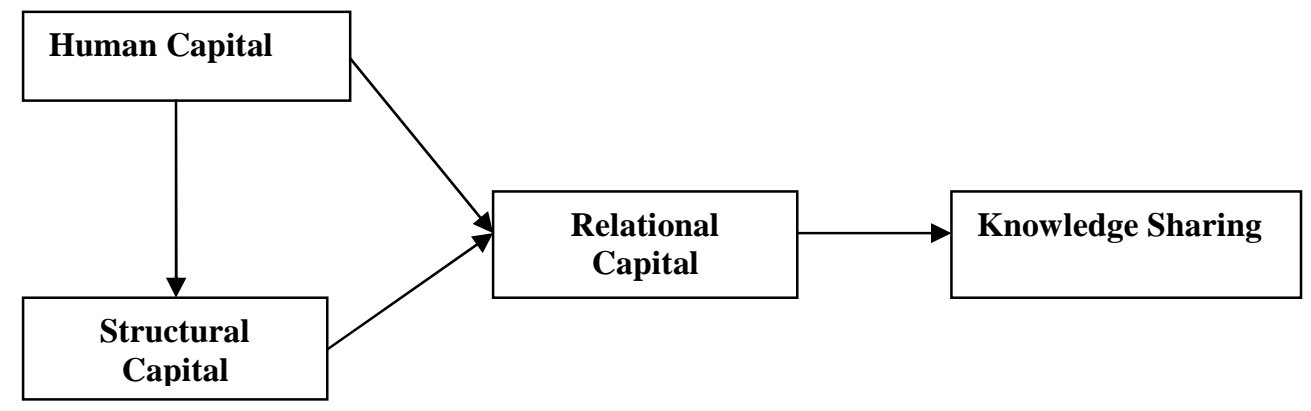

Figure 1.2 Proposed Framework 
The aim of this study is to evaluate the effects of intellectual capital elements on knowledge sharing. Intellectual capital was measured in accordance to Bontis et al (1998), Chen et al (2005), Cohen and Kaimenakis (2007), Narver and Slater (1990) and Deshpande et al (1993). Knowledge sharing was measured using items from Haldin-Herrgard (2000), Bock and Kim (2002), Ipe (2003), Husted et al (2005), Chieh-Peng Lin (2007), Calatone et al (2002), Liebowitz(1999), Choi and Lee (2002). All items were measured on a seven point Likert-type scale where $1=$ strong disagree and 7 = strongly agree.

The sample was drawn from Small and Medium enterprises (SMEs) in Malaysia. The list of SMEs of manufacturing was acquired from Small and Medium Enterprises Corporation (SMIDEC) that administer the manufacturing SMEs in Malaysia. 1000 questionnaires had been distributed by mail.
Two weeks after distribution, a phone call was made as a reminder. A total of 336 questionnaires are useable which indicated $34 \%$ which is considered an effective response rate. This response rate is similar to other surveys in Malaysia, which tend to obtain a response of between 15-25 per cent (Sarachek and Aziz, 1983; Rozhan, 1991).

\section{Results and Discussion}

Table 1.2 shows the respondents' profile based on the organization. Most of respondents are from manufacturing industry which is the biggest industry player in Malaysia SMEs. A total of $58.2 \%$ of SMEs are in partnership while $29.7 \%$ have been operating more than 10 years. Based on the number of employees and annual turnover, $55.6 \%$ and $64.4 \%$ of respondents are in small enterprises respectively.

Table 1.2 Respondent Organization Profiles

\begin{tabular}{|c|c|c|}
\hline Profile & Frequency & $\%$ \\
\hline $\begin{array}{l}\text { Type of Industry } \\
\text { - } \quad \text { Manufacturing } \\
\text { - } \quad \text { Services }\end{array}$ & $\begin{array}{l}242 \\
193\end{array}$ & $\begin{array}{l}55.6 \\
44.4\end{array}$ \\
\hline $\begin{array}{l}\text { No of employee } \\
\text { - } \quad \text { Small (Between } 5 \text { to } 19 \text { employees) } \\
\text { - } \quad \text { Medium (Between } 20 \text { to } 150 \text { employees) }\end{array}$ & $\begin{array}{l}242 \\
193\end{array}$ & $\begin{array}{l}55.6 \\
44.4\end{array}$ \\
\hline $\begin{array}{ll}\text { Annual Turnover } \\
\text { - } \\
\text { - } & \text { Medium ( between RM200,000 and less than RM1 million) } \\
& \text { Metween RM1 million and RM5 million) }\end{array}$ & $\begin{array}{l}280 \\
155\end{array}$ & $\begin{array}{l}64.4 \\
35.6\end{array}$ \\
\hline $\begin{array}{ll}\text { Type of Ownership } \\
\text { - } & \text { Sole-proprietor } \\
\text { - } & \text { Family-owned } \\
\text { - } & \text { Partnership }\end{array}$ & $\begin{array}{l}104 \\
78 \\
253\end{array}$ & $\begin{array}{l}23.9 \\
17.9 \\
58.2\end{array}$ \\
\hline 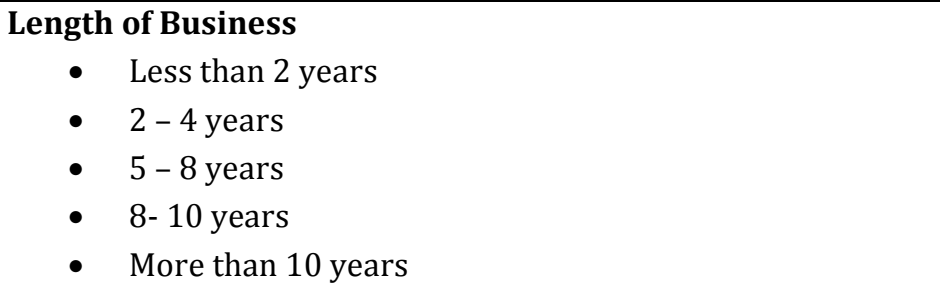 & $\begin{array}{l}39 \\
108 \\
108 \\
51 \\
129\end{array}$ & $\begin{array}{l}9.0 \\
24.8 \\
24.8 \\
17.7 \\
29.7\end{array}$ \\
\hline
\end{tabular}


Table 1.3 shows the respondent profile of the individual which is based on the current position, education level, previous working experience, years of working experience and area of expertise. Most of respondents are owners (25.3\%) followed by executives
$(23.2 \%)$ and managers $(22.3 \%)$. Most of them are degree holders $(42.3 \%)$ who have previous working experience (76.8\%). 41.7\% have more than 5 years of working experience in business areas (17.3\%).

Table 1.3 Respondents Individual Profile

\begin{tabular}{|c|c|c|}
\hline Profile & Frequency & $\%$ \\
\hline \multicolumn{3}{|l|}{ Current position } \\
\hline - Owner & 85 & 25.3 \\
\hline - Co-Owner & 42 & 12.9 \\
\hline - $\quad$ Partner & 39 & 11.6 \\
\hline - $\quad$ Manager & 75 & 22.3 \\
\hline - $\quad$ Executive & 78 & 23.2 \\
\hline - Director & 16 & 4.8 \\
\hline \multicolumn{3}{|l|}{ Education level } \\
\hline - SPM/STPM & 57 & 17 \\
\hline - $\quad$ Certificate & 14 & 4.2 \\
\hline - Diploma & 76 & 22.6 \\
\hline - Degree & 142 & 42.3 \\
\hline - $\quad$ Master & 26 & 7.7 \\
\hline - Professional Qualification & 14 & 4.2 \\
\hline \multicolumn{3}{|l|}{ Years of previous working experience } \\
\hline - No working experience & 78 & 23.2 \\
\hline - With working experience & 178 & 76.8 \\
\hline \multicolumn{3}{|l|}{ Years of working experience } \\
\hline - Less than 1 year & 41 & 12.2 \\
\hline - $1-2$ years & 32 & 9.5 \\
\hline - 2-5 years & 31 & 9.2 \\
\hline - More than 5 years & 131 & 41.7 \\
\hline \multicolumn{3}{|l|}{ Area of experience } \\
\hline - Business & 58 & 17.3 \\
\hline - Finance & 15 & 4.5 \\
\hline - Accounting & 16 & 4.8 \\
\hline - Engineering & 19 & 5.7 \\
\hline - Science & 4 & 1.2 \\
\hline - IT & 6 & 1.8 \\
\hline - Engineering & 15 & 4.5 \\
\hline - Operation & 6 & 1.8 \\
\hline - Architecture/Design & 2 & 0.6 \\
\hline - Construction & 1 & 0.3 \\
\hline - Logistic & 3 & 0.9 \\
\hline - $\quad$ Others & 1 & 71.4 \\
\hline
\end{tabular}




\section{Reliability Test}

The reliability of an instrument refers to its ability to produce consistent and stable measurements. Kumar (1996) explains that reliability can be seen from two sides: reliability (the extent of accuracy) and unreliability (the extent of inaccuracy). The most common reliability coefficient is the Cronbach's alpha which estimates internal consistency by determining how all items on a test relate to all other items and to the total test - internal coherence of data. The reliability is expressed as a coefficient between 0 and 1.00. The higher the coefficient, the more reliable is the test. The result of study showed that Cronbach's alpha reliability coefficient for human capital is 0.869 , structural capital is 0.903 , relational capital is 0.898, knowledge sharing of knowledge value is 0.904 and social network is 0.847 indicating that this instrument is a reliable measure. A measure should have a Cronbach's alpha of at least 0.6 or 0.7 and preferably closer to 0.9 to be considered useful (Aron and Aron, 2002; Sekaran, 2002). Table 1.4 lists detailed scores of Cronbach's coefficient alpha. Since all the Cronbach's alpha values are over the critical point of 0.7 showing that the survey's reliability is accepted.

Table 1.4 Reliability Test Results

\begin{tabular}{|l|l|l|l|}
\hline \multicolumn{2}{|l|}{ Variables } & $\begin{array}{l}\text { Reliability } \\
\text { Cronbach's } \\
\text { Alpha }\end{array}$ & \\
\hline \multirow{2}{|c|}{$\begin{array}{l}\text { Intellectual } \\
\text { Capital (IC) }\end{array}$} & Human Capital (HC) & 0.869 & Accepted \\
\cline { 2 - 4 } & $\begin{array}{l}\text { Structural Capital } \\
\text { (SC) }\end{array}$ & 0.903 & Accepted \\
\cline { 2 - 4 } & $\begin{array}{l}\text { Relational Capital } \\
\text { (RC) }\end{array}$ & 0.898 & Accepted \\
\hline $\begin{array}{l}\text { Knowledge } \\
\text { Sharing (KS) }\end{array}$ & & 0.904 & Accepted \\
\hline
\end{tabular}

Table 1.5 shows the result of fit for each measurement. The Normed $\chi^{2}$ ranges from 2.079 to 2.793 , all below the recommended threshold of 3.0; (Hair et al. 2006)). RMSEA values (from $0.057-0.077$ ) are below the recommended cut-of-points of 0.08 (Hair et al.2006). The values of GFI (from 0.948 0.988), CFI (from $0.072-0.996$ ) and TLI (from 0.961 - 0.991) are all above the recommended threshold of 0.90 (Hair et al. 2006). The intellectual capital(IC) is made up of three constructs namely; human capital (HC), structural capital (SC) and relational capital (RC). These results show that the models under consideration exhibit good fits.

Table 1.5 Fit Results for Measurement Models after Instrument Validation

\begin{tabular}{|c|c|c|c|c|c|c|c|c|c|}
\hline \multicolumn{2}{|l|}{ Construct } & \multirow{2}{*}{$\begin{array}{l}\text { Number } \\
\text { of Items } \\
\text { Dropped }\end{array}$} & \multicolumn{7}{|l|}{ Fits } \\
\hline & & & $\chi^{2}$ & Df & $\begin{array}{l}\chi^{2} / d \\
f\end{array}$ & RMSEA & GFI & CFI & TLI \\
\hline \multirow{3}{*}{$\begin{array}{l}\text { INTELLECTUA } \\
\text { L CAPITAL }\end{array}$} & $\mathrm{HC}$ & 4 & \multirow{3}{*}{$\begin{array}{l}104.75 \\
8\end{array}$} & \multirow[t]{3}{*}{41} & \multirow{3}{*}{$\begin{array}{l}2.55 \\
5\end{array}$} & \multirow[t]{3}{*}{0.068} & \multirow[t]{3}{*}{0.947} & \multirow{3}{*}{$\begin{array}{l}0.97 \\
8\end{array}$} & \multirow{3}{*}{$\begin{array}{l}0.97 \\
1\end{array}$} \\
\hline & SC & 5 & & & & & & & \\
\hline & $\mathrm{RC}$ & 4 & & & & & & & \\
\hline \multicolumn{2}{|l|}{ KS } & 5 & 27.785 & 13 & $\begin{array}{l}2.13 \\
7\end{array}$ & 0.058 & 0.978 & $\begin{array}{l}0.99 \\
2\end{array}$ & $\begin{array}{l}0.98 \\
7\end{array}$ \\
\hline
\end{tabular}


In addition, Table 1.6 presents the summary of the measurement model showing the values for the standard regression weights ranging from 0.512 to 0.908 , all above the 0.5 lower level limit recommended by Hair et al. (2006). The t-values (critical ratios) range from 13.013 to 25.902 , all greater than 2 and significantly with $\mathrm{p}=0.000$ (Hair et al. 2006). The construct reliability, ranges from 0.81 to 0.94 , higher than the recommended value of 0.7 by Hair et al. (2006). Variance extracted is from 0.55 to 0.74 . The lower side of the variance extracted is just above the threshold of 0.5 recommended by Hair et al. (2006).

Table 1.6 Summary of Other Results of the Measurement Models

\begin{tabular}{|l|l|l|l|l|}
\hline Variable/Construct & $\begin{array}{l}\text { Range of } \\
\text { Regression } \\
\text { Weight for 1 } \\
\text { Order Latent } \\
\text { Variable }\end{array}$ & $\begin{array}{l}\text { Range of Critical } \\
\text { Ratios (t-values) } \\
\text { for Regression } \\
\text { Weights }\end{array}$ & $\begin{array}{l}\text { Construct } \\
\text { Reliability } \\
\text { (CR) }\end{array}$ & $\begin{array}{l}\text { Variance } \\
\text { Extracted } \\
\text { (VE) }\end{array}$ \\
\hline HC & $0.572-0.813$ & $10.661-16.205$ & 0.85 & 0.53 \\
\hline SC & $0.789-0.876$ & $12.064-17.479$ & 0.85 & 0.58 \\
\hline RC & $0.666-0.774$ & $12.535-15.242$ & 0.84 & 0.56 \\
\hline KS & $0.525-0.868$ & $9.866-17.588$ & 0.83 & 0.62 \\
\hline
\end{tabular}

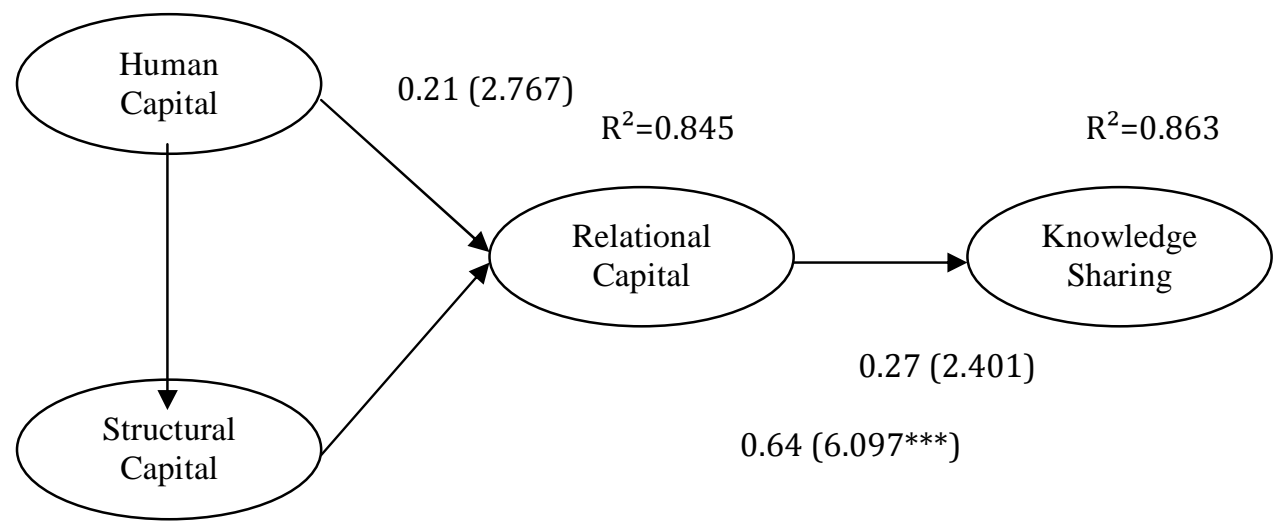

Figure 1.3 Structural Model

The Normed $\chi^{2}$ was 1.99 , CFI was 0.944 , TLI was 0.939 while RMSEA was 0.055 respectively. The Normed $\chi^{2}$ meets the threshold requirement of less than 3 while CFI and TLI values are above 0.9 thresholds. RMSEA shows a good model fit. All threshold points are according to Hair et al. (2006). The standardized coefficient of the effect of relational capital on knowledge sharing provides support to hypothesis $\mathrm{H} 4$ with path coefficient of 0.673 , t-value 11.853 and significant at $\mathrm{p}<0.05$. The path coefficient of 
the effect of human capital and relational capital is not significant at $0.053(\mathrm{t}=0.628)$ while the path coefficient of human capital to structural capital is 0.916 (11.400). The path coefficient of structural capital to relational capital is $0.925(\mathrm{t}=9.454)$ and significant at $\mathrm{p}<0.05$. According to Chin (1998), only path coefficient of more than 3 is considered meaningful. Hypothesis $\mathrm{H} 2$ is not supported while Hypothesis H3 is supported. Jin Chen (2002) and Bontis et al (2002) found that even though human capital is important, it does not have direct relationship to dependent variable. It has indirect relationship with other capital such as structural capital and relational capital. Nevertheless, as IC, the human capital, structural capital and relational capital have $86 \%$ variance explained in knowledge sharing. This finding is similar to previous studies done by Lee and Choi (2003), Yang (2005), Cheng et al.,( 2008), Widen-Wuff and Suomi (2003), Darroch (2005), Nahapiet and Ghosal (1998), Gold et al. (2001) and Lee and Choi (2003).

\section{Conclusion}

Intellectual capital can play a critical role in forming an effective platform for knowledge sharing. The main idea is to observe the practices among SMEs in identifying their organizational resources. The organizational resources are well established in every organization and the issue is whether the internal factors (human capital and structural capital) compliment with its external factor (relationship to outsiders) in tapping the business opportunities. This framework offers another insights for SMEs to re-value their strengths and weaknesses and utilizing their routine activity of knowledge sharing for productivity.

The finding shows that the skill, knowledge and capability of employees do not contribute to the relationship of customers and other parties. SMEs should focus on this issue to connect its employees to the third parties which are very important for the business future. Relational capital plays a vital role in knowledge sharing compared to other dimensions of intellectual capital. The information and knowledge acquired and gathered from customers, suppliers and third parties are well shared which is very important for the organization to be ahead of competition and involve in innovation. However, human capital and structural capital should be addressed accordingly as they are the internal resources of the organization.

SMEs have a lot of advantages, being small in terms of size allows SMEs to forge strong bond among employees, developing close relationship with customers, creating opportunity to share knowledge with every employee and flexibility in any environment or situation. Through this framework, SMEs would be able to re-set their strategies especially in innovation to excel in competition. By embarking on knowledge, they should be better able to understand the needs and wants of the marketplace. This study offers an insight on how SMEs could capitalize on its knowledge which is embedded in its organization structure, relationship and people, through its common practice which is knowledge sharing, in order to be innovative. In this regard, SMEs should establish a knowledge culture. Rewards and incentives need to be put in place to motivate knowledge workers to share their knowledge and thus encourage creativity and innovation.

\section{References}

Appiah-Adu, K. \& Singh, S. (1998). "Customer Orientation and Performance: A Study of SMEs Management Decision," 6 (6) 385-394.

Aron, A. \& Aron, E. N. (2002). Statistics for the Behavioral and Social Sciences: A Brief Course, (2nd ed.). New Jersey: Upper Saddle River.

Bock, X. \& Kim, X. (2002). "Breaking the Myths of Rewards. An Exploratory Study of Attitudes about Knowledge Sharing," 
Information Resources Management Journal, 15 (2) 14- 21.

Boisot, M. (2002). 'The Creation and Sharing of Knowledge,' in Choo, C.W. and Bontis,N. (Eds). The Strategic Management of Intellectual Capital and Organizational Learning, Oxford University Press, Oxford.

Bond, M. H. \& Yang, K.-S. (1982). "Ethnic Affirmation Versus Cross-Cultural Accommodation: The Variable Impact of Questionnaire Language on Chinese Bilinguals in Hong Kong," Journal of CrossCulture Psychology. 13 (X) 169-185.

Bontis, N. (1998). "Intellectual Capital: An Exploratory Study that Develops Measures and Models," Management Decision, 36 (2) 63-76.

Bontis, N., Keow, W. C. C. \& Richardson, S. (2000). "Intellectual Capital and Business Performance in Malaysian Industries," Journal of Intellectual Capital, 1(1) 85-100.

Brennan, N. \& Cornel, B. (2000). "Intellectual Capital: Current Issues and Policy Implications," Journal of Intellectual Capital, 1 (3)

206-240.

Calantone, R. J. \& Cavusgil, S. T. \& Zhao, Y. (2002). "Learning Orientation, Firm Innovation Capability and Firm Performance," Industrial Marketing Management, 31 (X) 515-524.

Chen, J., Zhu, Z. \& Xie, H. H. (2004). 'Measuring Intellectual Capital: A New Model Innovativeness and Performance,' Journal of Business Research, 60 (X) 566-575.

Chen, M.-C., Cheng, S.-J. \& Hwang, Y. (2005). "An Empirical Investigation of the Relationship between Intellectual Capital and Firms' Market Value and Financial Performance," Journal of Intellectual Capital, 6(2) 159- 177.
Chen, S., Duan, Y. Edwards, J. S. \& Lehaney, B. (2006). "Toward Understanding InterOrganizational Knowledge Transfer Needs in SMEs: Insight from a UK Investigation," Journal of Knowledge Management, 10 (3) 623.

Chin, W. W. (1998). "Issues and Opinion on Structural Equation Modeling," MIS Quarterly. 22(1) 7-17.

Choi, B. \& Lee, H. (2003). “An Empirical Investigation of KM Styles and their Effect on Corporate Performance," Information and Management, 40 (X) 403-417.

Cohen, S. \& Kaimenakis, N. (2007). "Intellectual Capital and Corporate Performance in Knowledge-Intensive SMEs," The Learning Organization, 14 (3) 241-262.

Cohen, W. M. \& Levinthal, D. A. (1990). "Absorptive Capacity; A New Perspective on Learning and Innovation," Administrative Science Quarterly, 35 (X) 128-152.

Darroch, J. (2005). “Knowledge Management, Innovation and Firm Performance," Journal of Knowledge Management, 9(3) 101-115.

Decarolis, D. M. \& Deeds, D. L. (1999). “The Impact of Stocks and Flows of Organizational Knowledge on Firm Performance: An Empirical Investigation of Biotechnology Industry," Strategic Management Journal, 20 (X) 953-968.

De Pablos, P. O. (2004). "Measuring and Reporting Structural Capital: Lessons from European Learning Firms," Journal of Intellectual Capital, 5 (4) 629-647.

Edvinsson, L. \& Malone, M. (1997). 'Intellectual Capital,' Harper Business, New York.

Edvinsson, L. \& Sulivan, P. (1996). "Developing Model for Managing Intellectual Capital," European Management Journal, 14 (4) 356-364. 
Gold, H. A,. Malhotra, A. \& Segars, A. H. (2001). "Knowledge Management: An Organizational Capabilities Perspective," Journal of Management Information Systems, 18 (1) 185-214.

Gupta, A. K. \& Govindarajan, V. (2000). "Knowledge Management's Social Dimension: Lessons from Nucor Steel," MIT Sloan Management Review 42 (1) 71-80.

Guthrie, J. \& Petty, R. (2000). "Intellectual Capital: Australian Annual Reporting Practices," Journal of Intellectual Capital, 1(3) 241-251.

Hackerman, J. R. \& Morris, C. G. (1978). "Group Task, Group Interaction Process and Group Performance Effectiveness: A Review and Proposed Integration ${ }^{1}$," In L. Berkowitz (Ed), Group Process. New York; Academic Press, 1-15.

Hair, J. F., Jr., Black, W. C., Babin, B. J., Anderson, R. E. \& Tatham, R. l. (2006). Multivariate Data Analysis, 6th Edition, Pearson Education Inc., Upper Saddle River, NJ.

Hisrich, R. D. \& Peters, M. P. (2008). 'Entrepreneurship,' McGraw-Hill. Singapore.

Huber, G. P. (1991). “Organizational Learning: The Contributing Knowledge Processes and Literature," Organization Science, 2 (1) 88-115.

Husted, K. \& Michailova, S. (2005). 'Knowledge Sharing and Organizational Performance: The Role of Extrinsic and Intrinsic Motives,' 8th International Human Resource Management Conference, Cairns, Australia, Copenhagen Business School.

Ipe, M. (2003). "Knowledge Sharing on Organizations: A Conceptual Framework," Human Resource Development Review, 2 (4) 337-358.

Keskin, H. (2006). "Market Orientation, Learning Orientation, Innovation Capabilities in SMEs: An Extended Model," European Journal of Innovation Management, 9 (4) $396-417$.

Koenig, M. E. D. (1998). "From Intellectual Capital to Knowledge Management: What are they Talking about?" INSPEL, 32 (4) 222-233.

Kohli, A. K. \& Jaworski, B. J. (1990). "Market Orientation: The Construct, Research Propositions, and Managerial Implications," Journal of Marketing, 54 (2) 1-18.

Lee, H. \& Choi, B. (2003). "Knowledge Management Enablers, Processes and Organizational Performance: An Integrative View and Empirical Examination," Journal of Management Information Systems. 20 (1) 179-228.

Liebowitz, J. \& Chen, Y. (2001). "Developing Knowledge-Sharing Proficiencies," Knowledge Management Review, 3 (6) 12-15.

Lin, C.-P. (2007). "To Share or Not to Share: Modeling Tacit Knowledge Sharing, its Mediators and Antecedents," Journal of Business Ethics, 70 (X) 411-418.

Marr, B., Schiuma, G. \& Neely, A. (2004). "The Dynamics of Value Creation: Mapping your Intellectual Performance Drivers," Journal of Intellectual Capital, 5 (2) 312-325.

Martinez-Torres, M. R. (2006). "A Procedure to Design a Structural and Measurement Model of Intellectual Capital: An Exploratory Study," Information and Management, 43 (X) 617-626.

Narver, J. C. \& Slater, S. F. (1990). "The Effect of a Market Orientation on Business Profitability," The Journal of Marketing, 54 (4) 20-35.

Quink, U. ( 2008). “An Exploration of Knowledge Management and Intellectual Capital in Non-Profit Organization Context," Master Thesis. University of Queensland. Australia. 
Roos, J., Roos, G. \& Edvinsson, L. (1998). "Intellectual Capital: Navigating the New Business Landscape," New York University Press, New York.

Rozhan, O. (1998). 'Human Resource Management Practice of Service Organizations: Evidence from Selected Malaysian Firms,' Journal of Asia- Pacific Business, 2 (X) 65- 81.

Ruta, C. D. \& Macchitella, U. (2008). "Fostering Intellectual Capital through Communication Technologies: An Analysis of Knowledge Sharing Determinants," International Journal of Learning and Intellectual Capital, 5 (2) 123-152.

Sarachek, B. \& Aziz, A. H. (1983). 'A Survey of Malaysian Personnel Practices and Problems,' Journal Pengurusan, 2 (X) 61-79.

Sekaran, U. (2003). Research Methods for Business: A Skill Building Approach (4th Eds.) John Wiley and Sons, NY.

Stewart, T. A. (2000). 'Intellectual Capital: The New Wealth of Organizations,' London, Nicholas Brealey Publishing.

Subramaniam, M. \& Youndt, M. A. (2005). "The Influence of Intellectual Capital on the Types of Innovative Capabilities," Academy of Management Journal, 48 (3) 450-463.

Sveiby, K. E. \& Simons, R. (2002). "Collaborate Climate and Effectiveness of Knowledge Work - An Empirical Study," Journal of Knowledge Management, 6 (5) 420433.

Tan, H. P., Plowman, D. \& Hancock, P. (2008). "The Evolving Research on Intellectual Capital," Journal of Intellectual Capital, 9(4) 585-608.

Walsh, J. P. \& Ungson, G. R. (1991). "Organizational Memory," Academy of Management Review, 16 (X) 57-91.
Wickramansinghe, N. \& Sharma, S. K. (2005). "Key Factors that Hinder SMEs in Succeeding in Today's Knowledge-Based Economy," International Journal of Management and Enterprise Development, 2 (2) 141-157.

Widen-Wulff, G. \& Suomi, R. (2003). "Building a Knowledge Sharing Company - Evidence from the Finnish Insurance Industry," Proceedings of the 36th Hawaii International Conference on System Sciences.

Youndt, M. A., Subramaniam, M. \& Snell, S. A. (2004). "Intellectual Capital Profiles: An Examination of Investments and Returns," Journal of Management Studies, 41 (2) 335361. 